\title{
Absenteeism and associated factors: a study addressing the workers from a footwear manufacturer
}

\author{
Absenteísmo e fatores associados: estudo com trabalhadores de uma indústria calçadista
}

Ausentismo y factores asociados: estudio con trabajadores en una industria del calzado

\section{Daniela InêsThierRoloffa \\ Clarice Alves Bonow ${ }^{b}$ \\ Daiani Modernel Xavier ${ }^{a}$ \\ Mara Regina Santos da Silva ${ }^{a}$ \\ Adriane Maria Netto de Oliveira ${ }^{a}$ \\ Marta Regina Cezar-Vaz}

\section{How to cite this article:}

Roloff DIT, Bonow CA, Xavier DM, Silva MRS, Oliveira AMN, Cezar-Vaz MR. Absenteeism and associated factors: a study addressing the workers from a footwear manufacturer. Rev Gaúcha Enferm. 2021;42:e20200341. doi: https://doi. org/10.1590/1983-1447.2021.20200341 a Universidade Federal do Rio Grande (FURG), Escola de Enfermagem. Rio Grande, Rio Grande do Sul, Brasil.

Universidade Federal de Pelotas (UFPEL), Faculdade de Enfermagem. Pelotas, Rio Grande do Sul, Brasil.

\section{ABSTRACT}

Objectives: To characterize absenteeism among the workers of a footwear manufacturer and analyze associated factors. Method: This quantitative and cross-sectional study addressed 572 workers from a footwear company located in southern Brazil, totaling 1,902 sick leaves in 2017. Analyses considered absolute and relative frequencies, and univariate and multivariate Poisson regression models were performed.

Results: Most workers taking a leave from work were women with a job position in the operational sector to accompany a family member to attend a medical appointment or take exams. In the multivariate analysis, the following variables appeared associated with leaves longer than three days: being $\geq 50$ years older, working in the Production Support sector, working in the company from 16 to 20 years, and nine groups of diseases (ICD-10).

Conclusion: The findings contribute to understanding this industry's absenteeism profile, supporting strategies to promote positive economic and social impact, and promote adequate occupational health and safety.

Keywords: Absenteeism. Industry. Shoes. Occupational health. Occupational health nursing. Prevalence.

\section{RESUMO}

Objetivos: Caracterizar 0 absenteísmo de trabalhadores de uma indústria do setor calçadista e analisar fatores associados com 0 tempo de afastamento dos trabalhadores.

Método: Trata-se de um estudo quantitativo e transversal com 572 trabalhadores calçadistas do Sul do Brasil que tiveram 1902 eventos de afastamento no ano de 2017. As analises foram realizadas tanto por frequências absolutas e relativas, quanto usando 0 modelo de Regressão de Poisson univariada e multivariada.

Resultados: Predomínio do sexo feminino; de setor e cargo operacionais; de atestados médicos e de motivos de afastamento por acompanhamento familiar, consultas e exames. Na análise multivariada, mantiveram associação com mais de três dias de afastamento: idade $\geq 50$ anos, setor Apoio à Produção e tempo de trabalho na empresa de 16 a 20 anos, além de nove grupos de doenças do CID-10. Conclusão: Os achados contribuem na compreensão do perfil de absenteísmo da indústria, favorecendo o planejamento de estratégias assertivas aos impactos econômicos e sociais e adequada assistência à saúde e segurança do trabalhador. Palavras-chave: Absenteísmo. Indústrias. Sapatos. Saúde do trabalhador. Enfermagem do trabalho. Prevalência.

\section{RESUMEN}

Objetivos: Caracterizar el absentismo de los trabajadores en una industria en el sector del calzado y analizar los factores asociados con el tiempo de ausencia de los trabajadores.

Método: Se trata de un estudio cuantitativo y transversal realizado con572 trabajadores del calzado en el sur de Brasil que tuvieron 1902 eventos de abandono en 2017. Los análisis se realizaron tanto por frecuencias absolutas como relativas y utilizando el modelo de regresión de Poisson univariado y multivariado.

Resultados: Predominio femenino; sector operativo y cargo; certificados médicos y motivos de ausencia por seguimiento familiar, consultas y reconocimientos. En el análisis multivariado, mantuvieron asociación con más de tres días de ausencia: edad $\geq 50$ años, sector de Apoyo a la Producción y tiempo de trabajo en la empresa de 16 a 20 años, además de nueve grupos de enfermedades de la ICD-10. Conclusión: Tales hallazgos contribuyen a la comprensión del perfil de absentismo de la industria, favoreciendo la planificación de estrategias asertivas a los impactos económicos y sociales y la asistencia adecuada a la salud y seguridad de los trabajadores. Palabras clave: Absentismo. Industrias. Zapatos. Salud laboral. Enfermería del trabajo. Prevalencia. 


\section{INTRODUCTION}

The absenteeism phenomenon is a complex issue for companies because it negatively affects productivity, the costs to replace the workforce, and leads to decreased quality levels ${ }^{(1)}$. Conceptually, absenteeism means workers miss a workday or arrive late at work; it is work time lost when workers fail to show up for work, whether due to absence, delay, or some intervening reason, excluding vacation or any type of leave, such as maternity or paternity leave(2).

The causes for absenteeism may vary: medical or family reasons, financial or transportation problems, or lack of motivation. Absenteeism may also have an organizational origin, such as poor supervision and leadership, increasingly simpler tasks, lack of motivation and stimuli, inadequate working conditions, and conflicting relationships between workers and their employers ${ }^{(3)}$.

In this context, absenteeism became a topic studied in the most diverse environments, both nationally and internationally ${ }^{(4-5)}$, showing the importance of its scientific approach, considering that the absence of workers is no longer merely a medical issue but a more comprehensive matter. Additionally, it represents implications for the health and safety of workers in addition to being socially, legally, and economically important for workers, their families, co-workers, companies, and the state, constituting a considerable public health problem.

In this study, absenteeism-illness is considered absenteeism justified with a sick note provided by a physician, dentist, or other health worker or a declaration that the worker accompanied a family member in a medical appointment or exam. The workers addressed in this study are from the footwear industry.

Epidemiological data show the impact of absenteeism on organizations and the importance of addressing it. According to the International Labor Organization (ILO), there are 160 million cases of work-related illnesses every year, which added to occupational accidents, lead to an annual loss of $4 \%$ of the Gross Domestic Product (PIB) in the world ${ }^{(6)}$. Chronic diseases, musculoskeletal disorders, and mental and behavioral disorders are among the most common and costly work-related problems worldwide ${ }^{(7)}$.

In 2017, approximately 550,000 occupational accidents were reported in Brazil,340,229 of which were typical occupational accidents (i.e., occurred within the work environment), and 9,700 were work-related illnesses. In both cases, a Communication of Work Accident (CAT) was issued.
In the same year, approximately 313,000 occupational accidents resulted in sick leaves of less than 15 days, and slightly more than 140,000 resulted in sick leaves longer than 15 days. Note that Brazilian employers are responsible for paying workers up to 15 days of leave, and the INSS pays from the $16^{\text {th }}$ onwards, as workers are entitled to an occupational-accident benefit ${ }^{(8)}$.

This study addresses the context of manufacturing companies, specifically in the footwear industry. This economic activity is labor-intensive, with highly artisanal content, requiring individuals to exert physical effort, but does not require high professional qualification. For this reason, the workforce is highly exploited, with heavy workloads and long working hours, high turnover, and simplified tasks(9), which compromise the health and safety of workers, leading to sick leaves.

This study results from inter-institutional cooperation between university, industry, and social services entity, through the Programa de Gestão do Absenteísmo [Absenteeism Management Program], which is applied in most Brazilian states. The Program is intended to analyze absenteeism caused by illnesses through various monitoring actions and management of events causing leaves, analysis of Accident Prevention Factor (FAP), epidemiological management, nexus of social security benefits, measures to prevent occupational illnesses, and accidents, turnover, and legislation.

Hence, understanding the profile of absenteeism in one industrial sector and associated factors support the identification of its causes and the planning of strategies to minimize economic, social and health impacts. Additionally, it is the basis for appropriate health care provided to workers, with measures to prevent accidents and illnesses and promote health, managed and implemented by the occupational health team, in particular, occupational health nurses.

Some theoretical-methodological categories from Karl Marx's $s^{(10)}$ conceptions regarding labor within capitalism are adopted to discuss the work process, working conditions, and how these reflect on the workers' health-disease continuum.

Therefore, the following questions are asked: How the absenteeism of workers in a company in the footwear industry is characterized? What factors are associated with these workers'length of leave? Therefore, this study's objective was to characterize the absenteeism of workers in a manufacturer in the footwear industry and analyze factors associated with the workers' length of leave. 


\section{METHOD}

This is an analytical, cross-sectional study in which retrospective data concerning absenteeism were collected. Secondary data were collected from a footwear manufacturer that belongs to a multinational company located in the south of Brazil. In 2017, it comprised 1,394 workers (between admissions and dismissals), with 607 women and 787 men.

The footwear industry participated in a pilot project addressing the management of absenteeism that generated a database with absenteeism events. These events consisted of sick notes issued by physicians, dentists, or other health workers in addition to declarations that workers accompanied family members to medical appointments and exams between March and December 2017. The company's nursing team developed this database at the Serviço Especializado em Engenharia de Segurança e em Medicina do Trabalho (SESMT) [Specialized Service in Safety Engineering and Occupational Medicine]. These sick notes and declarations were received daily and used as a data source for this study.

The first database included 2,125 events. The inclusion criterion was having at least one absenteeism event from March to December 2017, justified by a sick note or declaration of having accompanied a family member to a medical appointment or exam. The exclusion criterion was having presented a document missing the ICD-10 information (International Statistical Classification of Diseases and Related Health Problems - 10th revision) ${ }^{(11)}$ or not describing the reason for the leave when asked by the health team upon delivering the document. Therefore, 223 events were excluded, so that 1,902 events submitted by 572 workers remained. The database was made available by the entities involved and was treated in September 2019.

The following variables were addressed to characterize absenteeism in the footwear industry and analyze associated factors: sex, age group, sector, job position, how long the individual worked at the company, type of document presented (sick note or declaration), place of consultation (in the company or outside the company), duration of sick leave (days missed), month, and ICD group.

Data were analyzed using the Statistical Package for Social Science (SPSS), version 21.0, described by absolute and relative frequencies, in addition to prevalence ratio. For the comparative analysis, the events were divided into two groups: leaves of less than three days and sick leaves from three to 15 days. This division considered a practice of companies of analyzing leaves longer than three days, an understanding that concerns measures to prevent long leaves and incapacity for work. For this reason, this is the group on which this study focuses.

Univariate and multivariate Poisson regression analyses were used. The criterion for a variable to be included in the multivariate model was presenting a $p$-value $<0.20$ in the univariate analysis and a $p$-value $<0.10$ to remain in the final model; the significance value was established at 5\% $(p \leq 0.05)$. Note that the number of some variables does not correspond to the number of absenteeism events ( $n=1,902)$; however, we opt for keeping them because the difference is small and does not result in statistical bias.

This study was approved by the Institutional Review Board at the Federal University of Rio Grande (CEPAS/FURG), with opinion report No. 3.497.585, on August 9 $9^{\text {th }}, 2019$, according to the ethical guidelines provided by resolution 466/2012, National Council of Health. This study resulted from inter-institutional cooperation between the Federal University of Rio Grande (FURG) through its Graduate Nursing Program, one footwear manufacturer, and the Industry's Social Service -Regional Department of Rio Grande do Sul (SESI/RS), holder of the Absenteeism Management Program and responsible for implementing the method in the pilot company and database.

\section{RESULTS}

A total of 1,902 leaves from 572 workers from a footwear manufacturer were identified. Note that female workers predominated, both in terms of total number of women on leave $[n=329$ (57.5\%) and men $n=241$ (42.1\%)] and number of events. Age ranged from 17 and 68 years old; most were aged between 40 and 49 .

The three units where leaves were the most frequent were the Sample Factory, Sewing, and the Administrative sector, which accounted for $75.9 \%$ of all leaves. The job position that most frequently missed work was that of samples operator with $67.5 \%$ of all the leaves and individuals working in the company from one to three years (44.6\%). Sick notes were the most common justifications (61.8\%), and the care unit most frequently sought was external to the company (80.1\%).

Of 1,902 leaves, 175 (9.2\%) referred to three or more days off work. Analysis of association between the variables and length of leaves indicated that longer sick leaves ( $\geq$ three days) were statistically significant among workers under 30 years old, from the Production Support sector, working in the company up to one year and from 16 to 20 years, presenting a sick note from a physician or dentist (Table 1). 
Roloff DIT, Bonow CA, Xavier DM, Silva MRS, Oliveira AMN, Cezar-Vaz MR

Table 1 - Characterization of absenteeism and association* between variables concerning leaves. South, Brazil, 2017 ( $\mathrm{n}=1,902)$

\begin{tabular}{|c|c|c|c|c|}
\hline Variables & $\begin{array}{c}\text { Total sample } \\
\text { n (\%) }\end{array}$ & $\begin{array}{l}\text { Prevalence of } \\
\text { Absenteeism } \geq 3 \\
\text { days (\%) }\end{array}$ & $\mathrm{PR}^{\dagger}\left(\mathrm{Cl}^{+} \mathbf{9 5} \%\right)$ & p-value \\
\hline \multicolumn{5}{|l|}{ Sex } \\
\hline Male & $557(29.3)$ & 10.1 & $1.14(0.84-1.53)$ & 0.412 \\
\hline Female & $1,343(70.7)$ & 8.9 & 1.0 & \\
\hline \multicolumn{5}{|l|}{ Age range } \\
\hline$<30$ years old & $368(19.3)$ & 10.9 & $1.49(1.00-2.21)$ & 0.050 \\
\hline 30 - 39 years old & $624(32.8)$ & 9.5 & $1.29(0.90-1.85)$ & 0.165 \\
\hline $40-49$ years old & $683(35.9)$ & 7.3 & 1.0 & \\
\hline$\geq 50$ years old & $227(11.9)$ & 11.5 & $1.57(0.99-2.45)$ & 0.051 \\
\hline \multicolumn{5}{|l|}{ Sector } \\
\hline Administrative & $249(13.1)$ & 10.8 & $3.69(0.52-26.3)$ & 0.193 \\
\hline Production Support & $48(2.5)$ & 22.9 & $7.79(1.06-57.5)$ & 0.044 \\
\hline Sewing & $315(16.6)$ & 11.1 & $3.78(0.53-26.7)$ & 0.183 \\
\hline Cutting & $50(2.6)$ & 8.0 & $2.72(0.32-23.3)$ & 0.361 \\
\hline Samples Factory & $878(46.2)$ & 8.0 & $2.71(0.39-18.9)$ & 0.315 \\
\hline Modeling & $158(8.3)$ & 8.9 & $3.01(0.41-22.1)$ & 0.279 \\
\hline Assembling & $82(4.3)$ & 8.5 & $2.90(0.37-22.7)$ & 0.310 \\
\hline Prefabricated & $30(1.6)$ & 6.7 & $2.27(0.22-23.8)$ & 0.495 \\
\hline Occupational health and safety & $9(0.5)$ & 0.0 & $\S$ & \\
\hline Maintenance & $34(1.8)$ & 2.9 & 1.0 & \\
\hline Matrix workshop & $23(1.2)$ & 8.7 & $2.96(0.28-30.7)$ & 0.364 \\
\hline Cafeteria and cleaning & $10(0.5)$ & 10.0 & $3.40(0.23-49.6)$ & 0.371 \\
\hline Chemical & $13(0.7)$ & 7.7 & $2.62(0.18-38.8)$ & 0.485 \\
\hline \multicolumn{5}{|l|}{ Most frequent job positions } \\
\hline Samples operator & $1,283(67.5)$ & 8.4 & $1.60(0.24-10.9)$ & 0.631 \\
\hline Assistant & $143(7.5)$ & 11.9 & $2.26(0.32-16.0)$ & 0.415 \\
\hline Analyst & $56(2.9)$ & 8.9 & $1.69(0.21-13.6)$ & 0.619 \\
\hline
\end{tabular}


Table 1 - Cont.

\begin{tabular}{|c|c|c|c|c|}
\hline Variables & $\begin{array}{l}\text { Total sample } \\
\text { n (\%) }\end{array}$ & $\begin{array}{c}\text { Prevalence of } \\
\text { Absenteeism } \geq 3 \\
\text { days }(\%)\end{array}$ & $\mathrm{PR}^{+}\left(\mathrm{Cl}^{\ddagger} 95 \%\right)$ & p-value \\
\hline Quality reviewer & $51(2.7)$ & 7.8 & $1.49(0.18-12.5)$ & 0.713 \\
\hline Technical pattern maker & $47(2.5)$ & 8.5 & $1.62(0.19-13.5)$ & 0.658 \\
\hline Shipper & $26(1.4)$ & 19.2 & $3.65(0.46-28.8)$ & 0.219 \\
\hline Coordinator & $23(1.2)$ & 13.0 & $2.48(0.28-21.9)$ & 0.415 \\
\hline Storekeeper & $19(1.0)$ & 5.3 & 1.0 & \\
\hline Maidservant & $19(1.0)$ & 5.3 & $1.00(0.07-14.8)$ & 1.000 \\
\hline Production support operator & $18(0.9)$ & 27.8 & $5.28(0.68-40.9)$ & 0.111 \\
\hline \multicolumn{5}{|l|}{ Experience in the company } \\
\hline Up to 1 year & $276(14.7)$ & 12.7 & $2.13(1.08-4.19)$ & 0.028 \\
\hline 1 to 3 years & $835(44.6)$ & 9.0 & $1.51(0.80-2.86)$ & 0.207 \\
\hline 4 to 5 years & $294(15.7)$ & 9.2 & $1.54(0.77-3.11)$ & 0.225 \\
\hline 6 to 10 years & $219(11.7)$ & 6.8 & $1.15(0.53-2.49)$ & 0.722 \\
\hline 11 to 15 years & $168(9.0)$ & 6.0 & 1.0 & \\
\hline 16 to20 years & $50(2.7)$ & 16.0 & $2.69(1.12-6.45)$ & 0.027 \\
\hline$>20$ years & $31(1.7)$ & 6.5 & $1.08(0.25-4.71)$ & 0.914 \\
\hline \multicolumn{5}{|l|}{ Type of document } \\
\hline $\begin{array}{l}\text { Sick note from other } \\
\text { health workers }\end{array}$ & $19(1.0)$ & 0.0 & $\S$ & \\
\hline Sick note written by a doctor & $1,176(61.8)$ & 14.3 & $45.1(11.2-181)$ & $<0.001$ \\
\hline Sick note written by a dentist & $75(3.9)$ & 6.7 & $21.1(4.16-106)$ & $<0.001$ \\
\hline $\begin{array}{l}\text { Declaration of having } \\
\text { accompanied a family member }\end{array}$ & $632(33.2)$ & 0.3 & 1.0 & \\
\hline \multicolumn{5}{|l|}{ Health Service } \\
\hline External & $1,524(80.1)$ & 8.7 & 1.0 & \\
\hline Internal & $378(19.9)$ & 11.1 & $1.27(0.92-1.77)$ & 0.149 \\
\hline
\end{tabular}

Source: Secondary data provided by a database, 2017.

*Poisson univariate regression PPR Prevalence ratio; ₹C195\%: 95\% Confidence interval; §lt was impossible to calculate the effect measure because there were no leaves with three or more days. The variables sex, sectors, and time working in the company presented $n<1,902$. 
The group of factors (ICD Z00-Z99) influenced the individuals' health and search for health care services the most and was the most prevalent reason for absenteeism (47.2\%). The groups presenting significant association with longer sick leaves ( $\geq$ three days) were neoplasm (ICD C00-D49), mental and behavioral disorders (ICD F00-F99), diseases of ear and mastoid (ICD H60-H95), diseases of the circulatory system (ICD 100-199), diseases of the musculoskeletal system and connective tissue (ICD M00-M99), pregnancy, childbirth, and puerperium (ICDO00-O99) injury, poisoning, and certain consequences of external causes (ICD s00-T98) (Table 2).

Table 2 - ICD groups and association* between workers' leaves, South, Brazil, $2017(n=1,902)$

\begin{tabular}{|c|c|c|c|c|}
\hline Variables & $\begin{array}{l}\text { Total sample } \\
\text { n (\%) }\end{array}$ & $\begin{array}{l}\text { Prevalence of } \\
\text { absenteeism } \\
\geq 3 \text { days (\%) }\end{array}$ & $\mathrm{PR}^{\dagger}\left(\mathrm{Cl}{ }^{\ddagger} 95 \%\right)$ & p-value \\
\hline \multicolumn{5}{|l|}{ ICD } \\
\hline A00-B99- Infectious and parasitic diseases & $54(2.8)$ & 9.3 & $4.29(1.29-14.3)$ & 0.018 \\
\hline C00-D48- Neoplasms (tumors) & $9(0.5)$ & 33.3 & $15.5(4.36-54.9)$ & $<0.001$ \\
\hline $\begin{array}{l}\text { D50-D89- Diseases of the blood and blood- } \\
\text { forming organs and certain disorders involving } \\
\text { the immune mechanism }\end{array}$ & $1(0.1)$ & 0.0 & $\S$ & \\
\hline $\begin{array}{l}\text { E00-E90- Endocrine, nutritional and } \\
\text { metabolic diseases }\end{array}$ & $11(0.6)$ & 0.0 & $\S$ & \\
\hline F00-F99- Mental and behavioral disorders & $97(5.1)$ & 17.5 & $8.13(3.09-21.4)$ & $<0.001$ \\
\hline $\begin{array}{l}\text { G00-G99- } \\
\text { Diseases of the nervous system }\end{array}$ & $25(1.3)$ & 4.0 & $1.87(0.23-15.3)$ & 0.565 \\
\hline H00-H59 -Diseases of the eye and adnexa & $84(4.4)$ & 7.1 & $3.31(1.04-10.6)$ & 0.043 \\
\hline H60-H95- Diseases of the ear and mastoid process & $15(0.8)$ & 20.0 & $9.28(2.45-35.2)$ & 0.001 \\
\hline 100-199- Diseases of the circulatory system & $50(2.6)$ & 12.0 & $5.57(1.77-17.5)$ & 0.003 \\
\hline J00-J99- Diseases of the respiratory system & $138(7.3)$ & 5.1 & $2.35(0.76-7.27)$ & 0.137 \\
\hline K00-K93- Diseases of the digestive system & $232(12.2)$ & 2.2 & 1.0 & \\
\hline $\begin{array}{l}\text { L00-L99- Diseases of the skin and } \\
\text { subcutaneous tissue }\end{array}$ & $29(1.5)$ & 3.4 & $1.60(0.19-13.2)$ & 0.663 \\
\hline $\begin{array}{l}\text { M00-M99- Diseases of the musculoskeletal system } \\
\text { and connective tissue }\end{array}$ & $88(4.6)$ & 17.0 & $7.91(2.96-21.1)$ & $<0.001$ \\
\hline N00-N99- Diseases of the genitourinary system & $36(1.9)$ & 2.8 & $1.29(0.16-10.7)$ & 0.814 \\
\hline O00-O99- Pregnancy, childbirth, puerperium & $24(1.3)$ & 54.2 & $25.1(9.79-64.5)$ & $<0.001$ \\
\hline $\begin{array}{l}\text { Ro0-R99-Symptoms, signs and abnormal clinical } \\
\text { and laboratory findings, not elsewhere classified }\end{array}$ & $19(1.0)$ & 5.3 & $2.44(0.30-19.9)$ & 0.404 \\
\hline
\end{tabular}


Table 2 - Cont.

\begin{tabular}{|c|c|c|c|c|}
\hline Variables & $\begin{array}{l}\text { Total sample } \\
\text { n (\%) }\end{array}$ & $\begin{array}{l}\text { Prevalence of } \\
\text { absenteeism } \\
\geq 3 \text { days }(\%)\end{array}$ & $\mathrm{PR}^{\dagger}\left(\mathrm{Cl}^{\ddagger} 95 \%\right)$ & p-value \\
\hline $\begin{array}{l}\text { So0-T98- Injury, poisoning, and certain other } \\
\text { consequences of external causes }\end{array}$ & $93(4.9)$ & 41.9 & $19.5(7.92-47.8)$ & $<0.001$ \\
\hline $\begin{array}{l}\text { Z00-Z99- Factors influencing health status and } \\
\text { contact with health services }\end{array}$ & $897(47.2)$ & 5.8 & $2.69(1.09-6.66)$ & 0.032 \\
\hline
\end{tabular}

Source: Secondary data from database, 2017.

*Univariate Poisson regression; PRR Prevalence Ratio; ₹(195\%: 95\% Confidence Interval; § It was impossible to calculate the effect measure because there were no leaves with three or more days.

Table 3 - Frequency of days absent from work and per month, South, Brazil, $2017(n=1,902)$

\begin{tabular}{lc} 
Variables & $\mathbf{n}(\mathbf{\%})$ \\
Absence from work & \\
None & $653(34.3)$ \\
1 day & $895(47.1)$ \\
2 days & $179(9.4)$ \\
3 days & $54(2.8)$ \\
4 to 6 days & $43(2.3)$ \\
7 to9 days & $29(1.5)$ \\
10 to14 days & $22(1.2)$ \\
15 days & $27(1.4)$ \\
Month & \\
March & $116(6.1)$ \\
April & $141(7.4)$ \\
May & $81(4.3)$ \\
June & $256(13.5)$ \\
July & $231(12.1)$ \\
August & $260(13.7)$ \\
September & $286(15.0)$ \\
October & $227(11.9)$ \\
November & $296(15.6)$ \\
December & $8(0.4)$ \\
\hline
\end{tabular}

Source: Secondary data from database, 2017
Regarding the length of leaves in the number of missed workdays, most events required none or one day off (81.4\%) justified with declarations that workers accompanied a family member to a medical appointment or exam. In addition, most leaves occurred in September (15\%) and November (15.6\%), whereas a small number of events was observed in December when the pilot project ceased collecting data and the company allowed collective annual leave (Table 3).

The multivariate Poisson regression model was used to control for confounding factors. The variables that remained significantly associated with longer leaves ( $\geq$ three days) were: age $\geq 50$ years old; Production Support sector; working from 16 to 20 years in the company; and some infectious/parasitic diseases, neoplasms, mental/behavioral disorders, diseases of ear/mastoid, diseases of the circulatory system, of the musculoskeletal system and connective tissues, pregnancy/childbirth/puerperium, other external causes, and accompanying a family member to a medical appointment(Table 4).

To complement the results, workers aged $50+$ years old presented a prevalence of $64 \%$ higher of sick leaves longer than three days than workers aged between 40 and 49 ( $P R=1.64 ; C 195 \%=1.03-2.60 ; p=0.038)$. Regarding the company's sectors, the leaves among workers from the Production Support were eight times longer ( $\geq 3$ days) than among workers from the Maintenance sector ( $P R=7.97$; $C 195 \%=1.01-62.8 ; p=0.049)$. Furthermore, those working in the company from 16 and 20 years old presented a prevalence of long leaves $215 \%$ higher than those working in the company from 11 to 15 years ( $P R=3.15 ; C 195 \%=134-7.42$; $\mathrm{p}=0.009)$, considering lower and higher prevalence ratios (PR), according to Table 1. 
Table 4 - Multivariate Poisson Regression Analysis* for factors independently associated with length of sick leave $\geq$ three days, South, Brazil, 2017 ( $\mathrm{n}=1902)$

\section{Variables}

Age

$\geq 50$ years old

Sector

Production Support

Years working in the company

16 to 20 years

ICD group

A00-B99- Infectious and parasitic diseases

C00-D48- Neoplasms (tumors)

F00-F99- Mental and behavioral disorders

H60-H95- Diseases of the ear and mastoid process

100-199- Diseases of the circulatory system

M00-M99- Diseases of the musculoskeletal system and

connective tissue

O00-099- Pregnancy, childbirth, puerperium

S00-T98- Injury, poisoning, and certain other consequences

of external causes

Z00-Z99- Factors influencing health status and contact with health services

\section{$\mathrm{PR}^{\dagger}\left(\mathrm{Cl}^{\ddagger} 95 \%\right)$}

$1,64(1,03-2,60)$

0,038

$7,97(1,01-62,8)$

0,049

$3,15(1,34-7,42)$

0,009

$\begin{array}{ll}4,13(1,24-13,8) & 0,021 \\ 12,5(3,12-49,7) & <0,001 \\ 7,56(2,87-19,9) & <0,001 \\ 7,95(2,11-29,9) & 0,002 \\ 4,98(1,59-15,5) & 0,006\end{array}$

$7,33(2,72-19,8)$

$<0,001$

$24,1(9,02-64,3)$

$<0,001$

$18,5(7,41-46,3)$

$<0,001$

$2,48(1,01-6,08)$

0,047

Source: Secondary data from database, 2017.

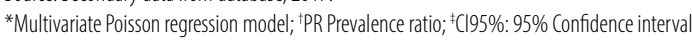

\section{DISCUSSION}

The results showed that women in the footwear manufacturer addressed in this study more frequently presented a profile of absenteeism, both in the number of women on sick leave, which was more significant than men and in the number of events. The results of a study addressing secondary data of workers on sick leave corroborate these findings. It reports that most were women aged $41+$ years old and worked in the institution from 11 to 30 years. The primary causes of leave were mental/behavioral disorders and musculoskeletal disorders ${ }^{(12)}$. Note that the predominance of women may be related to the fact that women more frequently seek health services than men and also because women need to miss work to attend medical appointments and take exams during prenatal.

Another relevant factor in the study previously mentioned was the workers' age, i.e., sick leaves were more prevalent 
among workers aged between 40 and 49 . A systematic review was conducted to identify absenteeism factors among Latin American countries and one characteristic of absenteeism was being $45+$ years old in addition to other factors, considering that the older a worker, the more frequent the leaves (medium and long duration), given the severity of diseases and the individuals' health conditions ${ }^{(13)}$.

Such an aspect is also in line with the association of age with leaves of three or more days, as reported in this study, showing that the health-disease continuum may influence leaves among workers 50+ years old. Additionally, there may be changes in job functions, professions, or retirement due to illnesses.

Another result reported was how long the individuals worked for the company; most leaves occurred between one to three years working in the company and declined over the years. One study analyzing sick notes presented by 883 workers from a company reported similar results concerning absenteeism due to illnesses, having worked in the company for two to five years, among other factors ${ }^{(14)}$. The frequency of workers'absence may decrease over time, considering that the most experienced workers already have gone through a period for the body to adapt to the productive process and its physical and mental demands.

However, the analysis showed a different result when time working in the company was associated with leaves equal to or longer than three days. A significant association was found between sick leaves among individuals working in the company from 16 to 20 years, showing that experienced individuals working for some time in the company tend to take longer sick leaves. It is important to consider that the reflexes of the work on workers'health may manifest at different points in time and are not easily predicted, with different effects on a company's absenteeism.

The fragmentation of specialized tasks characterizes the footwear production process, which is intended to promote greater productivity. However, this fragmentation is harmful to health and worsens the workers' performance ${ }^{(15)}$. This study's results confirm that the two sectors most frequently related to workers'absence were operational activities such as modeling, cutting, sewing, and shoe assembling.

Additionally, the job function accounting for $67.5 \%$ of the sick leaves was that of samples operator, who equally performs production tasks and tasks concerning sewing/ pre-manufacturing, assembling, and cutting, indicating that the production process may influence absenteeism in a company. It is important to note that the samples operator function is the function with the highest number of workers in the company given its operational nature; that is why it also presents a high number of sick leaves.
The shoe manufacturing process is always accompanied by factors that pose risks to the health and safety of workers so that they are vulnerable to biological, chemical, physical, and psychological risks ${ }^{(16)}$. One study analyzed two types of physical risks in a footwear manufacturer: thermal discomfort and continuous or intermittent noise. It verified that most sectors present discomfort and noise above normal parameters, indicating these environments are unhealthy for human work and influence the industry's levels of absenteeism ${ }^{(17)}$. The risks arising in footwear manufacturing environments may cause health problems, leading workers to miss work.

Given this context, Marx's conception enables a deeper reflection regarding the theoretical-methodological categories inherent to the capitalist society and its production process, which tend to be analyzed in the working process in the footwear industry.

Work is a participation process between human beings and nature, a mutual relationship in which individuals set in motion the natural body forces to appropriate natural resources, transforming oneself and transforming resources to satisfy their needs and modify their contexts ${ }^{(10)}$. Therefore, footwear workers embody the product of their work, producing a historical dimension of this process.

The characterization of the footwear fragmented and specialized production process is in line with the conception of the manufacturing division of labor, the operation of which is crystallized in the exclusive function of workers. Henceforth, workers become specialized, constituting a partial job, considered by capitalists a part of a collective workforce ${ }^{(10)}$.

The intensity of work is another factor interfering in workers'health-disease continuum. Intense work results from this production mode, considering that the division of labor in the footwear industry demands quality and productivity, in contrast to the protection of the workers' health. Workers may become objects of greed and corporate negligence, aggravating work-related illnesses and accidents.

According to Marx ${ }^{(10)}$, working time is the time during which a capitalist consumes the labor power s/he purchased. Therefore, if workers use this time to their benefit, they are "stealing" the capitalist employer. Hence, in the context of absenteeism, missing work is seen as time used for the employees' own benefit, even though the time is used to seek health care services.

However, Poisson's multivariate analysis showed that the Production Support sector was the unit most frequently associated with sick leaves equal to or longer than three days, showing that quality control, shipping, and warehouse activities take longer leaves. This result is different from the results reported by the other studies previously mentioned, relating absenteeism to the production of footwear and 
associated environmental risks. Furthermore, it suggests that longer leaves taken by a specific class of workers may have influenced the results; that is, more experienced workers who have already worked in other operational sectors may have problems related to previous activities, such as musculoskeletal disorders.

Another relevant aspect to consider in the results concerns the type of document presented; more than $60 \%$ of the absences were justified with sick notes. Some authors confirm that medical absenteeism is the type most frequently addressed in Brazil because it is possible to control, considering that companies require proof of sickness. A sick note justifies illnesses and maternity leave and the need to accompany a family member to attend a medical appointment or take routine exams ${ }^{(18)}$.

In the same sense, the results show that approximately $80 \%$ of the events occurred outside the company, showing an additional factor for workers' absence. Even though the company has an outpatient clinic and an occupational health team on its premises, the workers seek external services to meet their health needs.

This is a very current issue at the organizational level. Companies discuss the possibility of providing supplementary health care in the industrial context, considering the high costs added to collective corporate health plans/insurance, representing $13.1 \%$ of the companies' payrol|(19). Corporate health plans facilitate workers' access to health services; however, such access results in workers' absence.

In this sense, having Primary Health Care (PHC) available in organizational environments is an alternative to decrease absenteeism that results from workers seeking external health services provided by corporate health plans/insurance. Providing integrated health care that is focused on the prevention of diseases and health promotion, $\mathrm{PHC}$ prevents complications, emergency consultations, and chronic diseases with decreased costs and financially sustainable quality services ${ }^{(19)}$, which positively impact the rates of illnesses, occupational accidents, and absenteeism.

In this context of primary health care, occupational nurses compose the interdisciplinary team of the companies' SESMT. Occupational nurses have specific responsibilities and competencies that are essential to provide consistent, continuous, and quality health services within the work environment, based on preventing accidents/diseases and promoting health, influencing decreased risks, supporting productivity, improving the workers' quality of life, and favoring profitability ${ }^{(20)}$.

According to the study's results, almost half of the sick leaves among workers from a footwear manufacturer were related to ICDZ00-Z99, factors that influence health and contact with health services, concerning absence from work to accompany a family member to attend a medical appointment or take exams. This result suggests a lack of health care services in the work environment, forcing workers to take time away to seek external health care and satisfy their health needs. This context reinforces the importance of establishing a health care policy focused on $\mathrm{PHC}$, providing integral care at the individual and collective levels.

The second ICD group more frequently related to sick leaves was K00-K93, which includes, among others, oral care. In this sense, oral care is considered essential for the workers' integral health, and it is essential to include this specialty in the work environment. In addition, providing oral care in the work environment decreases absences due to dental care appointments outside the company and directly influences professional performance, considering that workers'exposure to mechanical, physical, chemical, and biological agents may cause occupational oral diseases ${ }^{(21)}$.

ICD J00-J99, the group that refers to diseases of the respiratory tract, was the group with the third-highest number of leaves in this study. Thus, there may be a relationship with seasonal diseases occurring in the cold season; the company is located in a state with rigorous winters. However, respiratory disorders are also associated with footwear production as workers are exposed to chemical agents present in some sectors.

In this sense, some authors claim that workers in the footwear industry are exposed to chemical risks, such as glue and adhesives used in the assembly of shoes and solvents to dissolve the raw material since such products emit vapors that are absorbed by the body through the respiratory tract and $\operatorname{skin}^{(9-15)}$.

Finally, it is essential to highlight that one of the ICD groups significantly associated with longer sick leaves was pregnancy. However, absences necessary to attend prenatal care or any medical appointments given the pregnancy are supported by Brazilian law and are not considered a problem but a historical achievement of working women.

\section{CONCLUSION}

This study identified that absenteeism among the workers of a footwear manufacturer located in southern Brazil was characterized by a predominance of middle-aged women working in the company from one to three years. Most workers absent from work were women, while women also presented the highest number of sick leaves. The sector and job functions that most frequently presented sick leaves were in the operational sector, and the absences were frequently justified with sick notes issued by 
professionals external to the company. The most frequent ICDs were $Z$ (accompanying family members to attend medical appointments or take exams), $\mathrm{K}$ (digestive), and $J$ (respiratory).

The factors that appeared with sick leaves equal to or greater than three days in the multivariate analysis were: $50+$ years old, Production Support, working in the company from 16 to 20 years, and ICD A-B (infectious and parasite diseases), C-D (neoplasms), F (mental and behavioral disorders), H (ear), I (circulatory system), M (musculoskeletal), O (pregnancy, childbirth and puerperium), S-T (injuries), and Z (accompanying family members to medical appointments and exams).

This study's limitations refer to the representativeness of the production sector and geographical coverage; only the absenteeism profile of one footwear manufacturer is presented here. Additionally, the study's cross-sectional is small, with data collected from March to December 2017. This period was determined by the institutions involved in the pilot project and did not include January and February, the months of summer vacation in Brazil, which may influence a company's absenteeism.

However, these limitations do not diminish this study's contribution because the model to manage absenteeism used in the pilot project can be adopted by other industries, favoring the development of actions intended to promote workers' health and well-being. Actions implemented by the occupational health and safety team, especially the nursing staff, contribute to the delivery of appropriate and quality health care to workers to prevent long sick leaves and incapacity to work.

This study is relevant because it not only describes the characteristics of a working population and analyzes the factors associated with the length of sick leaves, but it addresses the manufacturing environment, considering innovation and the production of scientific knowledge, through a partnership established between the university, entities specialized in occupational health and safety, and companies, intending to fill in gaps in knowledge concerning this topic and collaborating with scientific evidence to devise and manage public, social and economic policies at the local, regional, national and global levels.

\section{REFERENCES}

1. Andrade RD, Ferrari Junior GJ, Capistrano R, Teixeira CS, Beltrame TS, Felden EPG. Absenteísmo na indústria está associado com o trabalho em turnos e com problemas no sono. Cienc Trab. 2017;19(58):35-41. doi: https://doi.org/10.4067/ S0718-24492017000100035
2. Chiavenato I. Gestão de pessoas: o novo papel dos recursos humanos nas organizações. 4. ed. Barueri: Manole; 2014.

3. Bohn AC, Gripa S, Hein N, Kroenke A. Análise inter-relacional de indicadores de absenteísmo e turnover: 0 caso de uma indústria têxtil do litoral norte de Santa Catarina. Visão. 2018;7(1)95-110. doi: https://doi.org/10.33362/visa0.v7i1.1461

4. Santana LL,Sarquis LMM, BrevC, Miranda FMD, FelliVEA. Absenteeism due to mental disorders in health professionals at a hospital in southern Brazil. Rev Gaúcha Enferm. 2016;37(1):e53485. doi: https://doi.org/10.1590/1983-1447.2016.01.53485

5. Mekonnen TH, Lamessa SK, Wami SD. Sicknessrelated absenteeism and risk factors associated among flower farm industry workers in Bishoftu town, Southeast Ethiopia, 2018: a crosssectional study. BMC Res Notes. 2019;12:181. doi: https:// doi.org/10.1186/s13104-019-4223-2

6. Organización Internacional del Trabajo. La prevención de las enfermidades profesionales [Internet]. Ginebra; 2013 [citado 2020 maio 20]. Disponible en: https://www.ilo.org/wcmsp5/groups/public/---ed_protect/---protrav/--safework/documents/publication/wcms_209555.pdf

7. Pieper C, SchröerS, Eilerts AL. Evidence of work place interventions - a systematic review of systematic reviews. Int J Environ Res Public Health. 2019;16(19):3553. doi: https://doi.org/10.3390/ijerph16193553

8. Ministério da Fazenda (BR), Instituto Nacional do Seguro Social, Empresa de Tecnologia e Informações da Previdência. Anuário estatístico de acidentes do trabalho 2017 [Internet]. Brasilia (DF): 2017 [cited 2020 May 20]. Available from: http://sa.previdencia.gov.br/site/2018/09/AEAT-2017.pdf

9. Santos VHS. Segurança e saúde do trabalhador na indústria calçadista brasileira: um olhar preventivo para Sergipe. MLT. 2018 [cited 2020 May 20];4(2):77-88. Available from: https://periodicos.set.edu.br/index.php/ideiaseinovacao/article/ view/5610/2833

10. Marx K. 0 capital: crítica da economia política. 32. ed. Rio de Janeiro: Civilização Brasileira; 2014.

11. World Health Organization. International Classification of Diseases (ICD) [Internet]. Geneva: 2019 [cited 2020 May 20]. Available from: https://icd.who. int/browse10/2019/en

12. Fantazia MM, Bernardes JM, Dias A. Profile of illness among workers a university campus in the state of São Paulo: analysis of illness-related absenteeism. Occup Environ Med. 2018;75(2 Suppl.):A318-3. doi: https://doi.org/10.1136/ oemed-2018-ICOHabstracts.912

13. Tatamuez-Tarapuez RA, Domínguez AM, Matabanchoy-Tulcán SM. Revisión sistemática: factores asociados al ausentismo laboral en países de América Latina. Univ Salud. 2019;21(1):100-12. doi: https://doi.org/10.22267/rus.192101.143

14. Simões MRL, Rocha AM, Souza C. Factors associated with absenteeism-illness in rural workers in a timber company. Rev Latino-Am Enfermagem. 2012;20(4):71826. doi: https://doi.org/10.1590/S0104-11692012000400012

15. Santos M, Almeida A. Indústria do calçado: principais fatores de risco e riscos laborais, doenças profissionais associadas e medidas de proteção recomendadas. RPS0. 2018:5:576-s85. doi: https://doi.org/10.31252/RPS0.08.01.2018

16. Tualeka AR, Pathak Y, Wibrata DA, IImi B, Ahsan A, Rahmawati P, et al. Relationship of benzene exposure to trans, trans-muconic acid and blood profile of shoe workers in Romokalisari Surabaya, Indonesia. Open Acess Maced J Med Sci. 2019 [cited 2020 May 20];7(5):816-23. Available from: https://oamjms.eu/index.php/mjms/ article/view/oamims.2019.136/3033

17. Albuquerque DFF, Nóbrega JA, Melo RHF, Pires CA. Gerenciamento de riscos físicos em ambiente fabril de calçados. R Gest Industr. 2018;14(1):19-35. doi: https:// doi.org/10.3895/gi.v14n1.5749 
18. Oenning NSX, Carvalho FM, LimaVMC. Indicadores de absenteísmo e diagnósticos associados às licenças médicas de trabalhadores da área de serviços de uma indústria de petróleo. Rev Bras Saúde Ocup. 2012;37(125):150-8. doi: https:// doi.org/10.1590/S0303-76572012000100018

19. Confederação Nacional das Indústrias (BR) [Internet]. Grupo de trabalho das indústrias sobre saúde suplementar. Brasília (DF): 2019 [cited 2020 May 20]. Available from: http://www.portaldaindustria.com.br/sesi/canais/ gtss/\%23anchor-topo

\section{- Acknowledgment:}

To the Industry Social Service -Regional Department of Rio Grande do Sul (SESI/RS) and footwear manufacturer for inter-institutional cooperation and providing data. To the Laboratory of Socio-environmental Processes Studies and Collective Production of Health at the Federal University at Rio Grande (LAMSA/FURG).

\section{- Authors' contribution:}

Conceptualization: Daniela Inês Their Roloffand Marta

Regina Cezar-Vaz.

Formal analysis: Daniela Inês Thier Roloffand Marta

Regina Cezar-Vaz.

Investigation: Daniela Inês Thier Roloff.

Methodology: Daniela Inês Thier Roloffand Marta

Regina Cezar-Vaz.

Project's administration: Daniela Inês Thier Roloffand

Marta Regina Cezar-Vaz.

Supervision: Marta Regina Cezar-Vaz.

Validation: Marta Regina Cezar-Vaz.

Visualization: Daniela Inês Thier Roloff, Clarice Alves

Bonow, Daiani Modernel Xavier, Mara Regina Santos da

Silva, Adriane Maria Netto de Oliveira and Marta Regina

Cezar-Vaz.

Redaction - original draft: Daniela Inês Thier Roloff,

Clarice Alves Bonow, Daiani Modernel Xavier, Mara

Regina Santos da Silva, Adriane Maria Netto de Oliveira snf Marta Regina Cezar - Vaz.

Redaction - review and editing: Daniela Inês Their

Roloffand Marta Regina Cezar-Vaz.

The authors declare no conflicts of interest.

\section{- Corresponding author:}

Daniela Inês Their Roloff

E-mail: danythier@bol.com.br
20. Roloff DIT, Cezar-Vaz MR, Bonow CA, Lautert L, Sant'Anna CF, Couto AM. Occupational health nurses: interdisciplinary experience in occupational health. Rev Bras Enferm. 2016;69(5):842-55. doi: https://doi. org/10.1590/0034-7167-2015-0113

21. Marcelino E. Implantação de equipe de saúde do trabalhador nas empresas: um olhar sobre doenças ocupacionais com manifestação bucal. Braz Ap Sci Rev. 2018 [cited 2020 May 15];2(2):568-82. Available from: http://www.brjd.com. br/index.php/BASR/article/view/422/362 